\title{
BEST PRACTICES IN RESPONSIBLE MARKETING OF TOURISM: THE CASE OF CANADIAN MOUNTAIN HOLIDAYS
}

\section{INTRODUCTION}

The theory on sustainable tourism emphasizes the critical importance of environmental stewardship (Brandner et al., 1995; Bieger et al. 2000) particularly for those destinations in mountain areas (United Nations, 1993). Similarly a common thread running through all of the existing literature on competitiveness suggests that to be competitive, a company must be sustainable from an environmental perspective (d'Hauteserre, 2000; Crouch and Ritchie, 1999; Goeldner, Ritchie and McIntosh, 2000; Hassan, 2000). However, we are in a transitional phase of industrial history in which companies generally are still inexperienced in handling environmental issues creatively (Porter and van der Linde, 1995). A substantial fraction of environmental spending relates to the regulatory struggle itself and not to improving the environment, particularly in the service sector (Henriques and Sadorsky, 1996). But corporate managers in certain industry sectors have begun to consider environmental management a critical component for sustaining competitive advantage (Hunt and Auster, 1990; Barrett, 1992), and in the tourism industry it is time for managers to start recognizing environmental improvement as an economic and competitive opportunity, rather than an annoying cost or inevitable threat.

Yet, if environmental improvement is to provide a competitive opportunity there must be consideration of responsible marketing, defined here as the balancing of environmental 
initiatives and environmental communication in order to achieve sustainable competitive advantage. Unfortunately, there has been no consistent approach to environmental marketing practices in tourism. Some companies neglect their environmental obligations, perhaps due to lack of guidelines and examples of best practice, or perhaps because they don't understand the benefits (Hudson, 1996). Others exploit environmental communication for short-term gains, or fail to tell visitors about their environmental initiatives (Wight, 1994). This article proposes a model for responsible marketing that managers in the tourism industry can use to improve their environmental marketing practices, and applies the model to Canadian Mountain Holidays (CMH), a medium-sized Canadian tour operator.

\section{THEORETICAL FRAMEWORK}

\section{INSERT FIGURE 1}

Figure 1 has been developed as a framework for this study based on previous literature in marketing, and strategic and environmental management (Wartick and Cochran, 1985; Hunt and Auster, 1990; Meagher, 1991; Roome, 1992; Wight, 1994; Henriques and Sadorsky, 1996; Aragon-Correa, 1998). The model adopts the view that a company can be plotted on a two-by-two matrix to identify its position regarding responsible marketing. The vertical axis represents environmental action and the horizontal axis represents communication of these activities. Companies can take up one of four theoretical positions on the model. They can be classified as inactive when they tend not to see the benefits of allocating any resources toward environmental activities; they have 
a low level of commitment to both environmental improvement and to communication of environmental activities. Those that see the benefits of environmental action (perhaps for regulatory purposes), but fail to communicate these efforts are reactive. Companies that exploit consumer interests in environmentally friendly products without considerations of resource characteristics, environmental ethics or a long-term perspective are seen as exploitive. The position on the model most likely to remain sustainable (and competitive) is where environmental action and environmental communication of this action is high, and these organizations are labelled as proactive. Here the company and its associated products/services are developed sensitively, with regard to their long-term future, and consumers are aware (both before purchase and during the visit) of the concern for the resources involved.

It is important to recognize that a company's position on the model may only be temporary, as it may be in transit between one place in the model and the next. Further, there are likely to be a variety of contingency factors that will affect a company's position on the model. Previous research suggests that these influences include the level of environmental pressures from stakeholders (Henriques and Sadorsky, 1996), managerial interpretations of environmental issues (Sharma, 2000), the level of environmental regulations (Rugman and Verbeke, 1998), and the size and the financial position of the company (Aragon-Correa, 1998). 


\section{HELI-TOURISM AND CANADIAN MOUNTAIN HOLIDAYS}

One of the fastest growing sectors of the adventure tourism industry is heli-tourism (Thirkell, 1999). Under this catchy compound name, several subcategories have evolved, offering the public a diverse range of activities encompassing everything from heli-fly fishing to heli-picnicking. But the most popular are winter heli-skiing and summer helihiking. One company that specializes in both is Canadian Mountain Holiday (CMH). $\mathrm{CMH}$, a helicopter pioneer, was founded in 1965 and operates in 11 mountain areas of South Eastern British Columbia. The Banff-based company has annual revenues of about CDN\$50 million, and claims a 70 per cent repeat-booking figure. $\mathrm{CMH}$ holds license rights from the B.C. government to more than 15,000 square kilometres of remote territory in the Purcell, Cariboo, Selkirk and Monashee mountain ranges. $\mathrm{CMH}$ is several times the size of its next competitor in heli-ski visits, its operations include 30 helicopters, and seven remote lodges - many accessible in winter only by helicopter. There are three main strands to its business: heli-skiing; heli-hiking; and mountaineering.

Since 1965, CMH has experienced strong growth, but a challenge to this growth has appeared in the form of increased environmental awareness and opposition to such tourist activities by environmentalists. Some have raised concerns about the negative environmental impacts on fish and wildlife, about waste and fuel storage areas, and about noise pollution. Heli-tourism has not escaped this attention. In Europe, heli-skiing is technically banned in France and most of Switzerland and Austria because of environmental concerns, and environmentalists are beginning to focus their attention on 
North America. The East Kootenay Environmental Society (EKES) has emerged as a fierce opponent to tourism organizations who operate in British Columbia's (B.C.) backcountry. Claiming that BC's backcountry is home to 75 percent of the world's mountain goat population as well as being the last refuge for the endangered mountain caribou, EKES claim that heli-tourism seriously impacts their critical wildlife habitats and wild spaces.

\section{OBJECTIVES}

Unfortunately, the quality of marketing research for tourism organizations is still wholly inadequate and this is arguably the greatest single obstacle to the development of sustainable competitive strategies (Middleton and Hawkins, 1998). The objective of this study therefore, was to build on the research that exists on the complex relationship between tourism and the environment by applying the responsible marketing model to $\mathrm{CMH}$. By positioning tourism operators like $\mathrm{CMH}$ on the model, inconsistencies between the publicly stated policies of companies and their actions can be identified. Those organizations that achieve a balance between environmentally responsible action and communication of these activities can be used as role models in the industry, as proactive tourism operators that have gone beyond compliance have typically been guided by the practices of others (Todd and Williams, 1996). 


\section{METHODOLOGY}

Interviews with key stakeholders, observational research, and content analysis of communication materials, were used to identify how near CMH is to finding a balance between responsible action and the communication of these activities. Key stakeholders were identified using the 'snowball effect', and in-depth interviews were conducted with individuals from $\mathrm{CMH}$, other heli-tourism operators, environmental groups, the government, tourism action groups, and ski area associations. In the interviews the questions followed an interview guide format, with appropriate probes used to encourage an informal conversation. In all the interviews a few main concepts were explored with all the informants. These concepts were based on the marketing model described above.

Participant observational research took place during the heli-hiking summer training course for guides in 2002. Many authors believe that the distinctive capabilities of observational methodologies for investigating services phenomena have not yet been widely recognized (Crano and Brewer, 1986; Jorgensen, 1989; Grove and Fisk, 1992). A full discussion of the advantages and disadvantages of observational methods is not possible here, but there are several widely used classifications (see Boote and Mathews, 1999 for a brief outline of the most popular of these). In this study the author examined the operations of $\mathrm{CMH}$ in practice and looked for evidence of environmental initiatives to support the material gathered in the interviews. 
Content analysis was employed to examine the nature and level of communication of environmental activities by $\mathrm{CMH}$. Content analysis uses an objective, systematic approach to measure the meaning of communicated material through the classification and evaluation of selected words, themes or concepts. Content analysis has evolved since its introduction in the 1920s, largely in social science applications and has great promise as a tool for tourism marketing analysis (Fletcher, Witt and Moutinho, 1994). It has been the chosen methodology in most previous ethical code studies, and is useful as it seeks to understand data as symbolic phenomena and lends itself well to examining language in written documents (Krippendorff, 1980). All types of communication materials were analyzed including $\mathrm{CMH}$ brochures, Web pages, newsletters, press releases and videos. Interviews with guides and overseas agents provided further insights into the level of environmental communication given to consumers both before and during a holiday.

\section{RESULTS}

\section{$\underline{\text { Environmental Activities }}$}

\section{Environmental Policy}

As yet, $\mathrm{CMH}$ does not have a specific environmental policy. However, the company is close to publishing a new sustainability report, one of the first major tour operators in Canada to produce a corporate report of this kind. $\mathrm{CMH}$ has implemented a program called 'Second Nature', an in-house comprehensive program of social and environmental initiatives which is an attempt to put all of their environmental and sustainability projects 
under one umbrella (Hay, 2002). The company says that the environment has always been a cornerstone of its vision which is to "lead in safety, excellence of service and environmental harmony, maintaining the family atmosphere on which the company was founded"(CMH, 2002).

According to Eileen Fletcher, Tourism Development Coordinator for the Tourism Action Society of the Kootenays (TASK), CMH is the only operator in the Kootenays that has the resource capacity to sit back and think about visioning: $C M H$ 's understanding of environmental issues is usually about four years ahead of anyone else" she says. "The company is very often a source of information about where things are going to go... and because they are proactive, it has given them credibility in Government”. She believes that industry driven best practices are going to be important in the future, and it is "good business for CMH to observe best practices - CMH's clients are well educated and wouldn't buy products that have negative environmental impact” (Fletcher, 2001).

\section{Wildlife}

Over the years, $\mathrm{CMH}$ has trained its guides to keep a vigilant watch for wildlife. The guides plan their flying and skiing routes to avoid contact, and all wildlife sightings are provided annually to the B.C. Government for their overall management purposes. They use computer software to map wildlife sightings, and to maintain a sense, over time, about the areas where animals spend their time at various times of the year. $\mathrm{CMH}$ also looks to external biologists to give them a sense of how best to behave in these habitats. The goal according to Dave Butler "is to prevent disturbance, and to ensure that our 
activities don't contribute to mortality, or to changes in use of habitat, or changes in distribution of the animals across the landscape ... to work our operations so that the animals see us as a neutral influence in their lives" (Butler, 2002).

However, the company, according to industry experts, "is involved in a gruelling battle with the East Kootenay Environmental Society, over the impacts of heli-tourism on wildlife" (Spencer, 2001; Madson, 2002). EKES claim that heli-tourism seriously impacts the mountain goat and caribou. For example, the society claims that a twokilometre avoidance distance to goat habitat is strongly supported by research and provincial wildlife biologists. $\mathrm{CMH}$, University researchers and BCAL (the Crown Corporation in charge of land use tenures on Crown Land) say that research is not conclusive, and a further study of mountain goat reaction to helicopter use is presently proposed: "Their claims fail to recognize the many factors that are at work on these populations, including predation, habitat loss, hunting, weather, disease, etc." says Butler.

\section{Vegetation}

In the summer, existing trails are used where possible, and use is dispersed throughout each operating area so that impacts on fragile alpine environments are minimized. The company claims that the potential impact on the land in the winter is negligible because visitors leave only tracks in the snow. They also have the ABLE (Applying Backcountry Landscape Evaluations) project underway, where they are measuring and re-measuring a series of 250 permanent plots in their hiking areas, and looking at how these areas might 
be changing (or not) over time as a result of their activities. "This project has already allowed us to change and improve our hiking program”, says Butler, suggesting that perhaps there were some impacts to begin with.

\section{Garbage and Waste Management}

$\mathrm{CMH}$ claims to reduce waste at every opportunity. For example in the Adamant Lodge in the Selkirk Mountains, food waste (that used to be consumed by lodge pigs until footand-mouth scares encouraged $\mathrm{CMH}$ to change procedures) is eliminated by using a prototype composting system developed by the maintenance manager Duane Dukart. In 2002, CMH implemented the 'President's Award for Environmental Initiative', a program which empowers all staff to take a look at what they can change in their own jobs that will help the environment. Duane received the first President's Award for his efforts to promote environmental stewardship. The company also employs the latest technology in sewage treatment and use only environmentally friendly soaps and paper.

\section{Fuel Management}

Each of the helicopter fuelling locations use leading edge technology to prevent fuel spills from reaching the ground or the water. These systems include the use of engineered containment berms and a state of the art emergency spill response system. Use of the helicopters is minimized wherever possible as this is the greatest direct cost of operations. The fuel for the helicopters is stored at the lodges, and at remote fuel caches, using leading-edge storage facilities. 


\section{Energy and Recycling}

CMH continually seek to reduce the amount of fuel used for heating and power. For example, propane use has been reduced significantly by recycling the heat produced by generators to heat the water in the lodges. Most of the lodges are powered by diesel generators, while propane is used for heating and cooking. By using heat exchangers on the generators, they save about 30,000 litres of propane per area, per year. And by using low-flow shower-heads, energy efficient light bulbs, new methods of handling laundry, treating waste water and a full recycling program, they reduce energy consumption even further.

\section{Forest Harvesting and Trail Construction}

Guides at $\mathrm{CMH}$ are trained in the latest low-impact travel techniques for alpine areas, and they share these approaches with the visitors. In the summer they hike on routes that are hardy, such as rocky ridges and dry meadows. For the winter products, CMH works with local forestry companies coordinating efforts to harvest in ways that work best for skiers while reducing the visual impact of harvesting. Landing and pick-up locations are also placed in areas of minimum impact on the forest. To help rejuvenate the forests, the company plants a tree each year for each hiker and skier.

\section{Education and training}

According to the $\mathrm{CMH}$ brochure, "the company is committed to ensuring that guests who come from all over the world to experience the mountains will have the opportunity to learn more about these special areas." In addition, $\mathrm{CMH}$ wants to share this knowledge 
with educational institutions, community groups and other users of these special areas. For example, to help better educate hikers, vacationers and others about black and grizzly bears, CMH was an active participant in the 'Year of the Bear Program 2001' - a Heritage Stewardship and Learning Program sponsored by Parks Canada.

To run their operation $\mathrm{CMH}$ employs over 500 people, and training is taken very seriously. Guides are encouraged to share with the guests their techniques for low-impact travel in alpine areas, and each year, the company brings in experts to guide training to ensure that guides are kept up-to-date. "Last year, we had a top bear biologist in, giving us ideas about how to minimize our impacts on, and interactions with, bears. The year before, it was one of the mountain goat researchers", says Dave Butler.

\section{Community Relations}

$\mathrm{CMH}$ is also committed to contributing to, and remaining, an important part of the communities in which it operates. The company supports a range of community projects, sport teams and education institutions. In response to the tragic death of former President of CMH in 2001, the Mark Kingsbury Foundation was formed to act as a long-term legacy to support Kingsbury's vision and passion towards the environment. Employees have taken the lead in getting the Foundation up and running, and some of its purposes are:

to encourage, support and nurture projects and initiatives designed to protect and enhance the ecological and social components of sustainable tourism; to provide environmental 
education programs for tourism guides; and to support research projects designed to improve operational practices for tourism operations from an environmental perspective.

\section{Research and Knowledge}

One highly charged issue is the potential impact of heli-tourism on the mountain caribou. $\mathrm{CMH}$ and the British Columbia Helicopter and Snowcat Skiing Operators Association (BCHSSOA) are currently trying to move forward with a research project looking at the interactions between caribou and helicopter and snow-cat skiing that recently received the conceptual support of the province's Mountain Caribou Technical Advisory Committee (MCTAC). CMH has been involved in other wildlife conservation projects, an example being the Mountain Goat Research Program, which will evaluate the effects of commercial tourism in traditional goat habitat. $\mathrm{CMH}$ is also active in a Wolverine Research Project, a study of Wolverine habitat, a project that the company assists in conjunction with the Columbia Basin Fish and Wildlife Compensation Program.

\section{Connections to Regulatory Regimes}

$\mathrm{CMH}$ is a member of the British Columbia Helicopter and Snowcat Skiing Operators Association (BCHSSOA). The BCHSSOA represents 29 independent operating companies in Western Canada, each offering helicopter skiing, snow-cat skiing and/or helicopter hiking to its guests. Part of the BCHSSOA mandate is to set standards for environmental stewardship; act as a collective voice for backcountry ski operators to ensure members govern themselves in a responsible manner; and promote high mountain skiing as a viable eco-tourism industry. In September, 2001, BCHSSOA produced a 
draft discussion paper urging for a set of best practices to be maintained and up-dated by an Environmental Standards Committee (comprised of associated members and outside environmental consultants) of the BCHSSOA membership. The group has been asked to move the 'best practices' project forward. The intent is to take it to a point where compliance will be a condition of membership, and external (third-party) audits will be used to monitor and report compliance. As Dave Butler acknowledges "the key will be connecting (somehow..) with government and NGO's to ensure credibility”.

\section{Communication of Environmental Activities}

The evidence above suggests that $\mathrm{CMH}$ has been generally proactive in environmental initiatives, but does the company communicate these initiatives to the various publics? The company uses a number of communication avenues, and these are discussed in turn.

\section{Brochures}

$\mathrm{CMH}$ produces colourful brochures for each of its three brands (with winter brochures being produced in six languages). The 2002/2003 heli-skiing brochure has one page of 50 dedicated to "The Operation and our environment", and describes the major environmental initiatives the company is undertaking "to ensure the long-term viability of our mountain heritage". The summer heli-hiking brochure also has a page dedicated to "CMH and the environment", and begins by saying "environmental sensitivity is a priority at CMH and we view ourselves as stewards of these mountains". In the mountaineering brochure there is no mention of environmental initiatives, apart from a 
sentence about the lodges which are "designed to fit harmoniously within the mountain environment”.

CMH is also part of the 'Adventure Collection', a group of six adventure companies who have joined together to form an alliance based on the principle that each company is deeply committed to the environment and culture through which they travel. According to Chief Marketing Officer Marty von Neudegg, this is not a marketing alliance but rather a group formed to demonstrate that tourism can be a positive force rather than a negative one. However, the alliance has been criticized for being nothing more than a marketing alliance - an excuse to exchange mailing lists, and to combine itineraries to create new trips (Higgins, 2000). At the guides training course, these criticisms were justified when the $\mathrm{CEO}$ of $\mathrm{CMH}$, Walter Bruns, addressed the audience on the marketing benefits of this alliance.

\section{Newsletters}

CMH publishes a newsletter called "CMH News", previously known as "CMH HeliFacts". In the very first issue in 1998 there was a section called "CMH and the Environment" that talks about the "stewardship ethic" at CMH and the various environmental initiatives. Since then, the environment has always featured in the newsletters, and the most recent, published in the fall of 2002, included one page dedicated to the new President's Award for environmental initiatives, and another page profiled Director of Land Resources, Dave Butler, and his environmental accomplishments. 


\section{Web Site}

$\mathrm{CMH}$ has several Web pages dedicated to the company and the environment. For example, a link from the heli-skiing home page leads to a separate Web page titled "The Operation and our Environment”. CMH begins communicating its environmental initiatives via the Internet by saying "for nearly 40 years environmental sensitivity has been a priority at $\mathrm{CMH}$. We view ourselves as stewards of these mountains and take this responsibility very seriously”. There follows a list of some of the environmental initiatives the company is undertaking to "ensure the long-term viability of our mountain heritage”. Another link from the heli-hiking home page takes the surfer to a page titled "CMH and the environment" where the reader is informed about "low-flow shower heads and energy-efficient light bulbs, optional towel and linen replacement, recycling of cans, bottles and paper".

\section{Press Releases}

$\mathrm{CMH}$ is beginning to be more active in the public relations area, although some of the CMH guides expressed concerns that the company did not seem as 'media savvy' as the environmental groups: "EKES always has the first say on environmental issues, and we are left trying to clear our name”, one said. In a press release from 2001, the company promoted to the trade their involvement in the Year of the Bear Program. In the article titled “CMH adds 'Year of the Bear' to Wildlife Programs”, Dave Butler said “our teams development of a healthy respect for, and understanding of wildlife is crucial to our continued enjoyment of Canada's backcountry" (Canadatourism, 2001). CMH used this 
opportunity to publicize three other major wildlife conservation projects they were involved in: the Cariboo Recovery Project; the Mountain Goat Research Program; and the Wolverine Research Project. In the same year, on the Tourism Together Web site in July 2001, CMH publicized the Mark Kingsbury Foundation with a full-page article about the foundation and how donations could be made (Tourism Together, 2001).

\section{Videos}

Expensive videos are made for all three activities in up to six languages. In the most recent promotional videos for heli-skiing (A Guides View, 1999) and mountaineering (Reach Your Peak, 1998) there is no mention of the CMH environmental philosophy or its environmental initiatives. Once in a Lifetime (1998), the heli-hiking promotional video, does have more pictures of wildlife and suggests that guests can learn about the natural history of the mountains from their guides.

\section{Environmental Awards}

CMH made a submission for the first Travel Alberta Tourism Awards (ALTO) under the category of sustainable tourism in 2001. One of the authors of this paper was a judge for these awards and noted that the application did not included many of the initiatives that $\mathrm{CMH}$ undertake with regards to the environment. Although not successful on that occasion, they have begun to submit to other award programs such as ASTA (American Society of Travel Agents), and Oceans Blue Foundation in Canada. In fact the company received an honourable mention from Oceans Blue for their Starfish Awards in 2002. 


\section{Invitation Evenings}

CMH hosts "An evening with CMH" throughout North America, Europe, Japan and Australia. These are invitation only evenings where past guests are invited to bring their friends to an evening with CMH staff and guides. These events are very successful with conversion rates exceeding 75 percent of all participants. Although there is always some discussion of environmental issues at these evenings, "it is less an issue than is communicating the experience" (Huber, 2002).

\section{IMPLICATIONS AND RECOMMENDATIONS}

Is CMH engaged in responsible marketing, or just a "Green Wash exercise", as claimed by Kat Hartwig, Wilderness Recreation/Tourism Campaign Spokesperson for EKES (Hartwig, 2002)? The results of this study suggest that CMH is generally active in environmental issues and is in fact proactive in some. In B.C.'s tourism sector, many suggest the company has taken a lead role in a range of activities. Its willingness to support and chair the BCHSSOA's Environmental Standards Committee, and to produce a sustainability report is evidence of this. But some of the environmental actions, such as planting a tree for every skier or hiker, could be construed as ineffective. By taking external action that does not really strike to the heart of the problems caused by the nature of the business could lead to accusations of "tokenism" and may fall into the "exploitative" category of Figure 1. However, such action is an increasingly wellrecognised way of demonstrating a company's commitment to the environment in a similar way to the totemic, though often energy inefficient practice of recycling. 
In terms of communications, $\mathrm{CMH}$ "has been remiss in communicating its environmental activities. The company may pay towards research for example, but do not publicize it” (Spencer, 2001). Accusations of 'Green Wash' are supported by inconsistencies in statements concerning the Adventure Collection alliance, and $\mathrm{CMH}$ will have to address these, in order to avoid allegations of exploitation. In addition, statements like "our lodges are designed to fit harmoniously within the mountain environment" can be seen as the written equivalent to the practice of planting trees, in that without further explanation of the practices of the company it risks creating a cynicism and the company's message appears to be beyond its actions.

So on the evidence of the research, the authors would position CMH in the 'Reactive' quadrant of the model (see Figure 1), but the company appears to be moving towards a more sustainable position where there is a balance between environmentally responsible action and environmental communication of these activities - taking a 'Proactive' stance. To reach this 'desired position' on the model, the authors have made the following recommendations in terms of actions and communications.

Firstly, $\mathrm{CMH}$ could work towards developing an eco-label scheme for the heli-skiing industry. It seems highly probable that eco-labels will become increasingly important in tourism as in other industries (Buckley, 2001). A routine program of environmental benchmarking within the heli-skiing sector will be an important adjunct of an effective eco-labelling scheme. This will require companies like $\mathrm{CMH}$ to report regularly on their 
environmental management measures and performance. The sustainability document that $\mathrm{CMH}$ is working on can act as such a report, but should include unprecedented documentation of natural resource consumption and the associated pollution, and explain what the company is doing about it. $\mathrm{CMH}$ will have to ensure that representatives of concerned public agencies are consulted on an ongoing basis in the production of this report. Much can be gained through open discussion with the local communities and local environmental groups, particularly those who are heli-ski critics or development opponents. The environmental practices and results should also be published and made available to the general media in addition to interested groups.

Any new lodges should be built with the environment in mind. To date, $\mathrm{CMH}$ has not been proactive in this regard. Green development is an approach to design, construction and management that reduces the impact of buildings on the environment and offers many benefits to owners and occupants. These buildings use less energy and water, meaning they cost less to operate; they are more comfortable, often using natural ventilation and avoiding toxic adhesives and plastics; and they look better, blending into the environment and using sunlight to supplement heat and interior lighting. If lodges are to be replaced in the future they should follow Aspens' new summit lodge example and 'deconstruct' rather that bulldoze. Aspen have published Guidelines for Environmentally Sustainable Design and Construction of Aspen Skiing Company Buildings, intended to guide future development. 
In terms of communications, a strong public relations effort would promote CMH's green mission while educating and setting standards for the industry. The more powerful a business gets, the more likely it will come under scrutiny from stakeholders, and adopting cause related marketing could counter-balance the bad publicity emanating from this close scrutiny. Cause-related marketing is a rapidly expanding public relations trend in corporate America, particularly during a time when the public is increasingly cynical about big business (Earle, 2000; Wilkinson, 1999). Companies use cause marketing to contribute to the well being of society and to associate themselves with a positive cause that will reflect well on their corporate image. A weakness of cause marketing is that it is often short-term, opportunistic, and is seen by more and more people as self-serving and exploitive (Smith and Stodghill, 1994). It is therefore important that CMH adopt a cause - perhaps using the Mark Kingsbury Foundation as the vehicle - and make the cause an important part of the company's business by integrating a non-commercial, socially redeeming value system into the company's business plan and operations. This strategic philanthropy adds an element of trust to the relationship between the company, its customers and other stakeholders.

Stakeholder credibility would also be improved if CMH publicized its achievements. Winning environmental awards would be one way of doing this. Examples include the Starfish Award sponsored by the Oceans Blue Foundation in Canada, and the Golden Eagle Awards established to recognize the environmental contributions of the North American Ski Industry. CMH could also consider hosting a Symposium for 
Environmental Solutions, which would be an opportunity for employees, the Government and special interest groups to work together for the environment.

According to Mihalic (2000), since the environmental image, not the real environmental impact and environmental quality managerial efforts, influence the choice of tour operator, the environmental image of the company has to be communicated to the potential visitors. $\mathrm{CMH}$ could start by including a section on the environment in the mountaineering brochure. At the lodges the company could put "What You Can Do" posters up similar to the ' 6 steps to Sustainable Slopes' ads appearing in ski magazines that ask skiers to respect wildlife, be considerate, and get involved with others. There should be more emphasis on the environment in the promotional videos, and at invitation evenings potential guests should be given more information on CMH's environmental initiatives.

Other recommendations for $\mathrm{CMH}$ include running 'Ecology Lectures' to inspire and educate customers (maybe as an addition to the 'evenings with CMH'), employees and the community. Environmental education programs targeting all age groups could also be conducted at the lodges, especially during the summer season, and even themed 'environmental weeks' could be packaged. These weeks would emphasize the Ecoaccommodations, Eco-cuisine, Eco-service etc. and could be actively marketed using traditional mediums. Finally, the company Web site should be improved and updated regularly to emphasize environmental achievements. It should be designed to educated 
and involve guests, employees, and the public in the company's efforts to improve its environmental performance.

However, there are some limitations to being proactive. Mihalic warns that too many environmental initiatives can be harmful: "too many environmental signs, programs etc. cause confusion for potential customers, result in inflation of environmental brands and also lower the value of every single green brand" (Mihalic, 2000 p. 76). In addition, some employees at $\mathrm{CMH}$ question the wisdom of raising their heads up and saying "hey, we're doing a great job here". For example, one of the summer guides indicated that as soon as the company publicized its use of leading-edge storage facilities at remote fuel caches, the environmentalists - who were unaware of these fuel caches - began to criticize $\mathrm{CMH}$ for having such facilities in the wilderness: "it just gave them more ammunition in their crusade to get us out of here". Indeed, this may be a reason why the research by Rondinelli and Berry (2000) shows companies preferring to take actions internally rather than risk external actions, especially when the internal actions are more efficacious in achieving environmental improvements than those external to the organisation. However, once a company has raised its head above the parapet, then it is no longer possible to withdraw itself as a target. Communication of an environmental message can achieve many potential benefits including increased custom and better, more motivated employees, yet the possible cost of a raised profile is increased attention from groups seeking to ensure the message is matched by action. 


\section{REFERENCES}

Anon (2001). CMH adds 'Year of the Bear' to wildlife programs.

www.canadatourism.com, 10 April.

Anon (2001). Tourism Together News, www.tourismtogether.com, 6 June.

Aragon-Correa, J.A. (1998). Strategic proactivity and firm approach to the natural environment. Academy of Management Journal, 41(5), 556-567.

Barrett, S. (1992). Strategy and the environment. Columbia Journal of World Business, 27(3\&4), 202-208.

Bieger, T., Muller, H., Elsasse, H., \& OK FIS Alpine Ski WM Engadin 2003 (2000). Nachhaltigkeit der FIS Alppine Ski WM 2003 St. Moritz - Pontesina, Engadin. Eine Sportveranstaltung im Spannungsfeld zwischen wintschafltichen, okologischen und gesesllschaftlichen Anspruchen. St Gallen/Bern/Zuerich/St. Moritz, Switzerland.

Boote, J. \& Mathews, A. (1999). Saying is one thing; doing is another: the role of observation in marketing research. Qualitative Market Research: An International Journal, 2(1), 15-21. 
Brandner, B., Muller, H., Elsasser, H., Meier-Dahlbach, H.P, Sauvain, P., \& Sadler, U. (1995). Skitourismus: Von der Vergangenheit zion Potential der Zukumft. Teil IVSkitourismus und Nachhaltigkeit. Verlag Rugger AG, Zuerich, Switzerland.

Buckley, R. (2001). Tourism ecolabels. Annals of Tourism Research, 29(1), 183-208.

Butler, D. (2002). CMH Land Resources Director. Personal Interviews, 5 February and 20 June.

CMH Company brochure (2002). Banff, Canada: Canadian Mountain Holidays.

Crano, W.D. \& Brewer, M.B. (1986). Observational and archival data, in W.D. Crano, and M.B. Brewer (Eds.) Principles and Methods of Social Research, 279-309. Newton, MA: Allyn-Bacon.

Crouch. G. I. \& Ritchie, B.J.R. (2000). Tourism, competitiveness, and societal Prosperity. Journal of Business Research, 44, 137-152.

Earle, R. (2000). The Art of Cause Marketing, New York: McGraw-Hill.

Fletcher, E. (2001). Tourism Development Coordinator for the Tourism Action Society of the Kootenays (TASK). Personal Interview, 6 November. 
Fletcher, J.E., Witt, S.F. \& Moutinho, L. (1994). Analytical Methods Applied to Tourism, Hemel Hempsted: Prentice-Hall.

Goeldner, C. R., Ritchie, J. R. B. \& McIntosh, R. W. (2000). Tourism. Principles, Practices, Philosophies, New York: John Wiley \& Sons, Inc.

Grove, S.J. \& Fisk, R. (1992). Observational data collection methods for services marketing: an overview. Journal of the Academy of Marketing Science, 20(3), 217-224.

Hartwig, K. (2002). Wilderness Recreation/Tourism Campaign Spokesperson for EKES. Personal Interview, 2 January.

Hassan, S. S. (2000). Determinants of market competitiveness in an environmentally sustainable tourism industry. Journal of Travel Research, 38(3), 239-245.

d'Hauteserre, A. (2000). Lessons in managed destination competitiveness: the case of Foxwoods Casino Resort. Tourism Management, 21(1), 23-32.

Hay, J. (2002). CMH Staff Feature. CMH News, 40, 8.

Henriques, I. \& Sadorsky, P. (1996). The determinants of an environmentally responsive firm: an empirical approach. Journal of Environmental Economics and Management, 30(3), 381-395. 
Higgins, M. (2000). Takeoffs and landings. Wall Street Journal, 20 October.

Huber, S. (2002). European Sales Agent for CMH. Personal Interview, 8 April.

Hudson, S. (1996). The 'greening' of ski resorts: a necessity for sustainable tourism, or a marketing opportunity for skiing communities? Journal of Vacation Marketing, 2(2), 176-185.

Hunt, C.B. \& Auster, E.R. (1990). Proactive environmental management: avoiding the toxic trap. Sloan Management Review, 31(2), 7-18.

Jorgensen, D.L. (1989). Participant Observation: A Methodology for Human Studies, Newbury Park, CA: Sage Publications.

Krippendorff, K. (1980). Content Analysis: An Introduction to its Methodology, Beverly Hills: Sage.

Madson, R. (2002). President of R.K Heli-Ski. Personal Interview, 3 January.

Meagher, M. (1991). Canadian environmental marketing programs: how to walk the balance in making good environment into good business. In I. Rhind (Ed.) The Canadian Green Marketing Alert, 1(1), 7-10. 
Middleton, V.T.C. \& Hawkins, R. (1998). Sustainable Tourism: A Marketing

Perspective, Oxford: Butterworth-Heinemann.

Mihalic, T. (2000). Environmental management of a tourist destination: a factor of tourism competitiveness. Tourism Management, 21(1), 65-78.

Porter, M. \& van der Linde, C. (1995). Green and competitive. Harvard Business Review, September-October, 120-134.

Rondinelli, D.A. \& Berry, M.A (2000). Environmental citizenship in multinational corporations: social responsibility and sustainable development. European Management Journal, 18(1), 70-84

Roome, N. (1992). Developing environmental management systems. Business Strategy and the Environment, 1, 11-24.

Rugman, A.M. \& Verbeke, A. (1998). Corporate strategy and international environmental Policy. Journal of International Business Studies, 29(4), 819-833.

Sharma, S. (2000). Managerial interpretations and organizational context as predictors of corporate choice of environmental strategy. Academy of Management Journal, 34(4), 681-697. 
Smith, G. \& Stodghill, R. (1994). Are good causes good marketing? Business Week, 21 March, 64.

Spencer, J. (2001). CEO of Canada West Ski Areas. Personal Interview, 7 August.

Thirkell, K. (1999). View from the top. The Ottawa Citizen, October, 2, K1.

Todd, S.E. \& Williams, P.W. (1996). From white to green: a proposed environmental management system for ski areas. Journal of Sustainable Tourism, 4(3), 147-173.

United Nations (1993). Agenda 21: Programme of Action for Sustainable Development, New York: United Nations Department of Public Information.

von Neudegg, M. (2002). CMH Chief Marketing Officer. Personal Interview, 13 February.

Wartick, S.L. \& Cochran, P.L. (1985). The evolution of the corporate social performance model. Academy of Management Review, 10(4), 758-769.

Wight, P. (1994). Environmentally responsible marketing of tourism. In E. Cater and G. Lowman (Eds.) Ecotourism: A Sustainable Option?, 39-55. New York: John Wiley \& Son. 
Wilkinson, A. (1999). Cause for concern. Marketing Week, 11 February, 28-31. 
Figure 1: A Model for Responsible Marketing

\begin{tabular}{|c|c|c|}
\hline \multirow{4}{*}{$\begin{array}{l}\text { ENVIRONMENTALLY } \\
\text { RESPONSIBLE ACTION } \\
\text { Measured by analyzing: } \\
\text { Environmental policy } \\
\text { Policy on wildlife } \\
\text { Policy on vegetation } \\
\text { Waste management } \\
\text { Fuel management } \\
\text { Energy \& recycling } \\
\text { Forest harvesting } \\
\text { Education \& training } \\
\text { Community relations } \\
\text { Research \& knowledge } \\
\text { Connections to regulatory regimes }\end{array}$} & \multicolumn{2}{|c|}{$\begin{array}{l}\text { ENVIRONMENTAL COMMUNICATION } \\
\text { Measured by analysis of brochures, newsletters, websites, } \\
\text { company reports, press releases, signs, and awards. } \\
\text { LOW }\end{array}$} \\
\hline & $\begin{array}{l}\quad \text { INACTIVE } \\
\text { No support or involvement } \\
\text { from top management } \\
\text { Environmental management } \\
\text { not necessary } \\
\text { No environmental reporting } \\
\text { No employee environmental } \\
\text { training or involvement }\end{array}$ & $\begin{array}{l}\quad \text { EXPLOITIVE } \\
\text { Some involvement of top } \\
\text { management } \\
\text { Environmental issues dealt } \\
\text { with only when necessary } \\
\text { External reporting but no } \\
\text { internal reporting } \\
\text { Little employee training or } \\
\text { involvement }\end{array}$ \\
\hline & & \\
\hline & $\begin{array}{l}\quad \text { REACTIVE } \\
\text { Some involvement of } \\
\text { top management } \\
\text { Environmental management } \\
\text { is a worthwhile function } \\
\text { Internal reporting but no } \\
\text { external reporting } \\
\text { Some employee environmental } \\
\text { training or involvement }\end{array}$ & $\begin{array}{l}\quad \text { PROACTIVE } \\
\text { Top management involved in } \\
\text { environmental issues } \\
\text { Environmental management is } \\
\text { a priority item } \\
\text { Regular Internal and external } \\
\text { reporting including an } \\
\text { environmental plan or report } \\
\text { Employee environmental } \\
\text { training or involvement } \\
\text { encouraged }\end{array}$ \\
\hline
\end{tabular}

